\title{
THE
}

\section{Re-Placing Race in (White) Psychoanalytic Discourse: Founding Narratives of Feminism}

Jean Walton

University of Rhode Island, jwalton@uri.edu

Follow this and additional works at: https://digitalcommons.uri.edu/eng_facpubs

Terms of Use

All rights reserved under copyright.

\section{Citation/Publisher Attribution}

Walton, Jean. "Re-Placing Race in (White) Psychoanalytic Discourse: Founding Narratives of Feminism." Critical Inquiry, vol. 21, no. 4, 1995, pp. 775-804. JSTOR, JSTOR, www.jstor.org/stable/1344067.

Available at http://www.jstor.org/stable/1344067?origin=JSTOR-pdf

This Article is brought to you for free and open access by the English at DigitalCommons@URI. It has been accepted for inclusion in English Faculty Publications by an authorized administrator of DigitalCommons@URI. For more information, please contact digitalcommons-group@uri.edu. 
Re-Placing Race in (White) Psychoanalytic Discourse: Founding Narratives of Feminism Author(s): Jean Walton

Reviewed work(s):

Source: Critical Inquiry, Vol. 21, No. 4 (Summer, 1995), pp. 775-804

Published by: The University of Chicago Press

Stable URL: http://www.jstor.org/stable/1344067

Accessed: 28/02/2013 15:03

Your use of the JSTOR archive indicates your acceptance of the Terms \& Conditions of Use, available at http://www.jstor.org/page/info/about/policies/terms.jsp

JSTOR is a not-for-profit service that helps scholars, researchers, and students discover, use, and build upon a wide range of content in a trusted digital archive. We use information technology and tools to increase productivity and facilitate new forms of scholarship. For more information about JSTOR, please contact support@jstor.org.

The University of Chicago Press is collaborating with JSTOR to digitize, preserve and extend access to Critical Inquiry. 


\title{
Re-Placing Race in (White) Psychoanalytic Discourse: Founding Narratives of Feminism
}

\author{
Jean Walton
}

\section{Introduction}

It has become a commonplace for psychoanalytic feminist scholars to return to the "great debate" of the 1920s and 1930s, when central figures in the movement explored the question of whether an autonomous model of female sexuality should or could be delineated as distinct from the male-based model that had been privileged in Freud's accounts. Indeed, this debate is recapitulated in diverse collections of essays, in which the arguments of the original protagonists in the debate are variously summarized (Freud, Jeanne Lampl-de Groot, Helene Deutsch, Ruth Mack Brunswick, Marie Bonaparte, Karen Horney, Ernest Jones, Joan Riviere, Melanie Klein), and then contemporary analysts or theorists take up the arguments anew, extending or revising conceptualizations of "female sexuality" in both clinical and applied areas of psychoanalysis. ${ }^{1}$ Psy-

I would like to thank Mae Henderson for having provided a public forum for a short version of this paper by accepting it for the "Proprieties and Improprieties" Panel at the 1993 MLA Convention in Toronto, and Sally Drucker and James E. Morrison for inviting me to read the section on Riviere at the "Journey Proud" conference in Durham, N.C. in June 1994. I am indebted also to Lauren Berlant, Elizabeth Abel, and E. Ann Kaplan for encouraging me to complete the long version. Most important, Mary Cappello is to be credited for her invaluable observations, insights, and editorial advice during every stage of this project, as well as for inspiring me, by the example of her own rich and comprehensive scholarship, to broaden the scope of my critical undertakings.

1. According to Teresa Brennan, feminist texts of the 1970s and 1980s constitute the second "great debate" after a relative silence following the first debate of the 1920s and 
choanalysis has, in other words, been from its inception an explicit and obvious terrain for exploring and critiquing sexual and gendered difference. It has been both a tool for and obstacle to political intervention in gender and sexual oppression.

By contrast, until the work of Frantz Fanon in the 1950s, and, more recently, of other theorists in the last decade, psychoanalysis has not been seriously considered a likely arena for the exploration and critique of racialized constructions of subjectivity. ${ }^{2}$ As it was being institutionalized, psychoanalysis seemed to thrive on the "eternal problem" of how to extend and modify Freud's male-centered theories of sexual development so that they would be equally applicable to women, but it shrank from the charge that it was also focussed too narrowly on the subjectivity of the white, European patients who provided the clinical material from which it was elaborated. It is as if the integrity of the psychoanalytic project was threatened by the treatment of perceived and fantasized racial difference as potentially constitutive of psychic development. Perhaps

1930s. See Teresa Brennan, The Interpretation of the Flesh: Freud and Femininity (New York, 1992), p. 37. Before the second debate, notable publications included Marie Bonaparte, Female Sexuality, trans. John Rodker (New York, 1953) (which includes an overview of the early literature); Psychoanalysis and Female Sexuality, ed. Hendrik M. Ruitenbeek (New Haven, Conn., 1966) (with essays by Ernest Jones, Jeanne Lampl-de Groot, J. H. W. van Ophuijsen, Karen Horney, Helene Deutsch, Joan Riviere, Sandor Lorand, Bonaparte, Clara Thompson, Phyllis Greenacre, A. H. Maslow, Judd Marmor, and David A. Freedman); and Female Sexuality: New Psychoanalytic Views, trans. pub., ed. Janine Chasseguet-Smirgel (1964; Ann Arbor, Mich., 1970) (includes an overview of the early literature and essays by ChasseguetSmirgel, Christian David, Béla Grunberger, C.-J. Luquet-Parat, Maria Torok, and Joyce McDougall). The second debate, which is still in progress, got underway with the publication of Juliet Mitchell, Psychoanalysis and Feminism (Harmondsworth, 1974), and branched out into two main directions, one drawing from Lacan's work (for example, Jacques Lacan and the école freudienne, Feminine Sexuality, trans. Jacqueline Rose, ed. Mitchell and Rose [New York, 1982], with introductory essays by Rose and Mitchell recounting the early debate), the other, directly or indirectly, from Kleinian psychoanalysis (for example, Nancy Chodorow's object-relations oriented The Reproduction of Mothering: Psychoanalysis and the Sociology of Gender [Berkeley, 1978]). The participants in feminist psychoanalytic discourse around female sexuality over the past two and a half decades are too numerous to list in detail here.

2. For a sense of how little attention has been given to race in feminist intersections with psychoanalysis, see the following entries in Feminism and Psychoanalysis: A Critical Dictionary, ed. Elizabeth Wright (Oxford, 1992): "black feminist critique of psychoanalysis" by Biodun Iginla, "black feminist psychotherapy" by Beverly Greene, and "race/imperialism" by Rey Chow, who notes that "works devoting equal attention to race, imperialism, feminism and psychoanalysis are rare. This has much to do, historically, with the socially and econom-

Jean Walton is assistant professor of English and women's studies at the University of Rhode Island. She is currently writing a book on white women's fantasies of racial difference in psychoanalysis, film, and fiction. 
this integrity was, after all, based on psychoanalysis's unacknowledged racial whiteness.

A critic such as Bronislaw Malinowski, who questioned the ethnocentrism of psychoanalysis, was roundly and dismissively attacked by Ernest Jones in his 1928 review of the anthropologist's Sex and Repression in Savage Society. Malinowski's criticism of psychoanalysis, except for its evocation of the "savage" and "barbarous," seems just as valid and pressing today:

The complex exclusively known to the Freudian school, and assumed by them to be universal, I mean the Oedipus complex, corresponds essentially to our patrilineal Aryan family with the developed patria potestas, buttressed by Roman law and Christian morals, and accentuated by the modern economic conditions of the well-to-do bourgeoisie. Yet this complex is assumed to exist in every savage or barbarous society. This certainly cannot be correct. ${ }^{3}$

And elsewhere: "It is obvious that the infantile conflicts will not be the same in the lavish nursery of the wealthy bourgeois as in the cabin of the peasant, or in the one-room tenement of the poor working man"” ("R," p. 369). To challenge the universality of the Oedipus conflict was to threaten the psychoanalytic enterprise at its very foundations; Jones had to deflect such an argument by diagnosing Malinowski's critique as a patient's "resistance" to a painful psychological truth: "Dr. Malinowski breaks out into a vigorous repudiation of the psycho-analytical views

ically privileged status enjoyed by the practice of psychoanalysis in the West" (p. 363). Following are a few of the recent exceptions to the silence on race in psychoanalysis: Elizabeth Abel, "Race, Class, and Psychoanalysis? Opening Questions," in Conficts in Feminism, ed. Marianne Hirsch and Evelyn Fox Keller (New York, 1990), pp. 184-204; in the domain of psychoanalytically informed feminist film theory, see E. Ann Kaplan, "The Couch Affair: Gender and Race in Hollywood Transference," American Imago 50 (Winter 1993): 481-514, and Mary Ann Doane, "Dark Continents: Epistemologies of Racial and Sexual Difference in Psychoanalysis and the Cinema," Femmes Fatales: Feminism, Film Theory, Psychoanalysis (New York, 1991), pp. 209-48; hereafter abbreviated FF. Sander L. Gilman's ongoing work has been invaluable for its documentation of the relationship between race and gender in the medical, literary, sexological, and psychoanalytic discourses of the past two or three centuries; see, for example, his Difference and Pathology: Stereotypes of Sexuality, Race, and Madness (Ithaca, N.Y., 1985). Of note in the clinical domain are Patrick Colm Hogan, "The Politics of Otherness in Clinical Psychoanalysis: Racism as Pathogen in a Case of D. W. Winnicott," Literature and Psychology 38, no. 4 (1992): 36-43, and Dorothy Evans Holmes, "Race and Transference in Psychoanalysis and Psychotherapy," International Journal of Psycho-Analysis 73 (Spring 1992): 1-11, a continuation of a discussion that has been ongoing for the last decade and a half among clinical practitioners about the extent to which race is a factor in the psychotherapeutic situation.

3. Quoted in Ernest Jones, review of Sex and Repression in Savage Society, by Bronislaw Malinowski, International Journal of Psycho-Analysis 9 (July 1928): 365; hereafter abbreviated "R." 
about the Oedipus complex, denounces them as 'metaphysical,' and commits a number of easily avoidable misunderstandings of my statements which present all the familiar marks of 'unconscious resistance"” (" $R$," $p$. 368 ); or by caricaturing his argument, then countering it by implying that the sampling of analysands upon which the Oedipus complex was based was much more diverse than Malinowski realized:

It all comes of the wicked psycho-analytic habit of restricting their observations to the upper classes of the large European cities and not taking into account other classes and other races. Whatever makes Dr. Malinowski think that this is so? Has he not even heard of the existence of free psycho-analytical clinics? [“R," pp. 368-69]

Jones is not suggesting, of course, that the "savage" Trobrianders whose sexual life Malinowski constructs could be found seeking treatment in "free psycho-analytic clinics," but he does imply that patients who are to be found in such clinics (presumably the working classes and people of color) provide enough of a diverse sampling of humanity that conclusions based on them are applicable to people in all cultures, whatever their relative status in a given socioeconomic structure. Malinowski, who seemed at first to be an ally in demonstrating "the application of psychoanalytic methods to a savage race" (thereby proving these methods to be universal), had to be disowned by Jones because he "either denies altogether or reduces to the utmost shadowy proportions the three most fundamental tenets of psycho-analysis: the doctrines of infantile incest, of repression, and of the unconscious" ("R," p. 373). Early challenges to the androcentrism of Freud's theories led to vigorous and extended engagement in the questions of how subjects become gendered and sexualized; but as Jones's review of Malinowski's book demonstrates, comparable criticisms of psychoanalytic ethnocentrism had to be relegated to the "outside" of what was coming to be a powerful and influential institution, so that the question of how subjects become racialized could not even become a legitimate one within that institution. ${ }^{4}$

4. See Henrietta L. Moore's entry "anthropology and cross-cultural analysis" in Feminism and Psychoanalysis for more on the Jones/Malinowski controversy. According to Moore, their disagreement set the terms of debate about "what analytical weight and status should be given to cross-cultural variation" (p. 3). She notes that the result of their clash was "a split between anthropology and psychoanalysis," though her entry concerns itself more with this split's "profound effect on subsequent developments" in anthropology than on its implications for psychoanalysis (p. 3). For example, she notes evidence in anthropological research that "the concept of the person based on the humanist notion of the SUBJECT is not universal: concepts of the person and the acting, knowing subject vary enormously cross-culturally" (p. 7). She goes on: "It is evidence of this kind that could be used to produce a radical critique of certain psychoanalytic theories and to question assumptions about the universality of developmental processes; but anthropology has yet to produce such a critique" (p. 7). Nor, it could be argued, has psychoanalysis, insofar as it, too, has been 
Indeed, with a few notable exceptions, little has been asked throughout the history of psychoanalysis about what kind of knowledge might be produced if articulations of gendered subjectivity were considered in terms of their being dependent upon or imbricated in implicit assumptions about "whiteness" and "blackness," given that perceptions and fantasies of racial difference might form a significant axis of identity formation. In much of the early psychoanalytic literature, "femininity" or "masculinity" was coming to be understood as a "mature" stage one attained after successfully completing a developmental sequence that culminated in heterosexualized gendered adulthood. ${ }^{5}$ In the cases I will be considering here, however, it appears that a racial subtext informs this developmental model, in which maturity also implies the full assumption of a heterosexualized raced adulthood; according to this model, one must be fully "white" (or perhaps fully one's "race," however that might locally be constructed) in order fully to become a subject. Such a subtext could not become explicit, perhaps because early psychoanalysts would have argued that a male/female binary is a much more "universal" one than a black/white binary insofar as all humans are assumed to grow up in a context where they are distinguished from one another by gender, and where one is constituted by one's identification within and desire across that binary division. According to this argument, it would make sense to examine the impact of a gender division if one is attempting to elaborate (as the psychoanalysts were) a "universal" understanding of the human psyche, of human sexuality, of human desire and identification; but it would not make sense to interrogate how one identifies and desires as a racialized subject because not everyone is presumed to grow up affected by a black/white binary.

And yet, as I will demonstrate, psychoanalytic literature itself reveals that racialized binaries were and continue to be a reality in the world inhabited by Freud's patients and the patients of other psychoanalysts for as long as the institution has existed. Certainly this is the case for white Americans in a country with a very precise history of a racialized slavery system, of racialized lynching practices, of racialized divisions of labor, indeed, of a racialized history of child care, where the tasks of the "mother" so typically described in psychoanalytic accounts of early development (nursing, cleaning, eroticization of certain zones of the body, assistance in the acquisition of language, mediating in the mirror stage, where the child's image is misrecognized as his own) were (and continue

marked by its necessary disavowal of anthropology's questions since the Jones/Malinowski debate.

5. For a persuasive account of the heteroteleology in psychoanalytic accounts of gender acquisition, see Judith Butler, "Prohibition, Psychoanalysis, and the Production of the Heterosexual Matrix," Gender Trouble: Feminism and the Subversion of Identity (New York, 1990); hereafter abbreviated $G T$. 
to be) undertaken by black women in the white slave-owning or servantemploying household. It could be argued that it is just as much the case for Europeans, whose fantasmatic life is permeated by the Orientalist and Africanist ideologies that underwrite and justify what, by the time psychoanalysis was in its nascent stages, had become a long and vexed history of European colonialist expansion and decline. Yet in most psychoanalytic literature, which was concerned almost exclusively with white subjects, racial difference was only an intermittent and peripheral focus of attention. It only came up when, as in the case of Jones's review of Malinowski, psychoanalysts responded to the way in which their assumptions were borrowed or challenged by anthropologists. Even in these instances, fantasized or perceived racial difference was still not relevant to an understanding of how the white European subject was constructed; "race" functioned rather as a kind of untheorized but characteristic mark of a "primitive" culture that had not as yet been repressed by civilization and its discontents. "Race" was blackness, in other words, and seemed to have nothing to do with the "civilized" white human subject.

One need not even turn to the records of Jones's "free clinics" to find analysands who provided material with which racialized subjectivity could have been more explicitly theorized by psychoanalysis, even in the early years when the institution was being codified and consolidated as a scientific, clinical, and modernist institution. In the examples I will consider at length here, the constructions of racial difference provided by these white analysands are so deeply imbricated in their sexual and gender identities that it is curious that the analysts, who are otherwise at pains to make significant contributions to the understanding of female subjectivity, treat the references to race as though they are irrelevant. Subsequent readers of these texts have participated in what has come to be a hegemonic silence on the issue of race; and feminists, whose investment in the "great debate" of the 1920s around gender and sexuality has been perhaps the deepest of all, are unwitting participants in this collusion.

\section{2. (White) Femininity as a Masquerade in Joan Riviere}

One of the most frequently cited essays of the great debate of the 1920 s is Joan Riviere's 1929 paper "Womanliness as a Masquerade," which has repeatedly been deployed for its potential to deconstruct an essentialized notion of femininity and to characterize it, rather, as a "masquerade" in a phallic economy of desire that may or may not hide a repressed but potentially destabilizing female eroticism. As is evident from the work of Claire Johnston, Stephen Heath, Mary Ann Doane, John Fletcher, Teresa de Lauretis, and others, Riviere's essay (and Jacques Lacan's passing mention of masquerade in "The Meaning of the Phallus") 
has become a prime generative site for theoretical interventions in gendered subjectivity in the realm of feminist film theory. Elsewhere, Luce Irigaray draws upon the masquerade to posit a female desire that exceeds a dominant masculine economy; Judith Butler points up the extent to which the masquerade is indicative of a coercive heterocentric matrix; and Emily Apter critiques it, using it as a foil for her elaboration of a feminist ontology of femininity grounded in theories of female fetishism. ${ }^{6}$

Riviere's case study is indeed tantalizingly rich with implications; it provides a suggestive glimpse of the political and cultural milieu within which she practiced and wrote and could function as a crucial site at which to continue the project of historicizing the way in which psychoanalysis came to be institutionalized as a discursive and clinical instrument of control and resistance. Yet there is an explicit delineation of racial difference in the essay that has not been adequately explored; if feminists have been able to mobilize Riviere's work to reconceptualize female subjectivity, they have not, as yet, acknowledged how that subjectivity is a specifically white one, how it depends for its coherence on the figuring of black men on the one hand, and the elision of black women on the other. As Mary Ann Doane has pointed out (though not with reference to Riviere), "The force of the category of race in the constitution of Otherness within psychoanalysis should not be underestimated. . . Psychoanalysis can, from this point of view, be seen as a quite elaborate form of ethnography-as a writing of the ethnicity of the white Western psyche" (FF, p. 211).

A brief review of the key features of Riviere's essay will serve as a reminder of how striking it is that little has been made of its fantasy of racial difference. After announcing that she will demonstrate how "women who wish for masculinity may put on a mask of womanliness to avert anxiety and the retribution feared from men," Riviere introduces us to a "particular type of intellectual woman" whom she has been treating as a patient. ${ }^{7}$ The unnamed subject of this case study is described as "an American woman engaged in work of a propagandist nature, which

6. For the most extensive uses of the masquerade in film theory, see $F F$; Claire Johnston, "Femininity and the Masquerade: Anne of the Indies," in Psychoanalysis and Cinema, ed. E. Ann Kaplan (New York, 1990), pp. 64-72; Stephen Heath, "Joan Riviere and the Masquerade," in Formations of Fantasy, ed. Victor Burgin, James Donald, and Cora Kaplan (London, 1986), pp. 45-61; John Fletcher, “Versions of Masquerade," Screen 29 (Summer 1988): 43-70; and Teresa de Lauretis, "Recasting the Primal Scene: Film and Lesbian Representation," The Practice of Love: Lesbian Sexuality and Perverse Desire (Bloomington, Ind., 1994), hereafter abbreviated $P L$. Luce Irigaray draws on the masquerade in her This Sex Which Is Not One, trans. Catherine Porter (Ithaca, N.Y., 1985), pp. 83-85. Butler's incisive analysis of Riviere appears in GT, pp. 43-57, and Emily Apter critiques the masquerade in her Feminizing the Fetish: Psychoanalysis and Narrative Obsession in Turn-of-the-Century France (Ithaca, N.Y., 1991), pp. 65-98.

7. Joan Riviere, "Womanliness as a Masquerade," in Formations of Fantasy, p. 35; hereafter abbreviated "W." 
consisted principally in speaking and writing” (“W," p. 36). After every public performance, she is obsessed by a need for reassurance, which leads her "compulsively on any such occasion to seek some attention or complimentary notice from a man or men at the close of the proceedings in which she had taken part or been the principal figure; and it soon became evident that the men chosen for the purpose were always unmistakable father-figures" ("W," p. 36). Riviere goes on to say that this "masquerade" of womanliness (excessive "flirting and coquetting") is to be understood as a means of "propitiating" the potentially retaliatory father figure by offering herself to him sexually ("W," p. 37).

But when Riviere endeavors to trace this compensatory behavior to the woman's early fantasy life, we find the woman "defending" herself not against white, powerful father figures, but against another figure who might, like her, experience a similar anxiety about speaking from a position of authority: the black man living in the southern United States. Riviere tells us that

[this] phantasy [of offering herself sexually to a potential attacker] had been very common in her childhood and youth, which had been spent in the Southern States of America; if a negro came to attack her, she planned to defend herself by making him kiss her and make love to her (ultimately so that she could then deliver him over to justice). But there was a further determinant of the obsessive behavior. In a dream which had a rather similar content to this childhood phantasy, she was in terror alone in the house; then a negro came in and found her washing clothes, with her sleeves rolled up and arms exposed. She resisted him, with the secret intention of attracting him sexually, and he began to admire her arms and caress them and her breasts. The meaning was that she had killed father and mother and obtained everything for herself (alone in the house), became terrified of their retribution (expected shots through the window), and defended herself by taking on a menial rôle (washing clothes) and by washing off dirt and sweat, guilt and blood, everything she had obtained by the deed, and 'disguising herself' as merely a castrated woman. ["W," pp. 37-38]

Riviere interprets the "negro" of these phantasies as another of the power-wielding father figures who must be reassured that she has not stolen their masculinity: "In that guise [as castrated woman] the man [presumably the "negro" of the fantasy] found no stolen property on her which he need attack her to recover and, further, found her attractive as an object of love" ("W," p. 38). Apparently it makes no difference in Riviere's account that the "man" in question here is black, that culturally sanctioned fantasies in which a white woman is sexually attacked by a black man form a significant component of dominant white racist hegemony in the United States. Only the imagined attacker's gender is significant, not his race. 
As we shall see, Riviere's essay is similar to other instances in the 1910 s and 1920s when racial difference forms the content of the fantasy life of a white female subject, and yet it is not apparently a constitutive component of the psychoanalytic interpretation of the analyst. In other words, the explicit discourse on gender and sexuality of the period was informed by implicit assumptions about racial difference; because of its later importance for feminists, Riviere's essay is a crucial starting point from which to explore the ramifications of this double imbrication.

To facilitate such an exploration, it will be useful to note how the question of who does or does not have the penis in Riviere's text could be translated into a question of one's relation to the phallus as it is elaborated in Lacan's later discussion of masquerade in "The Meaning of the Phallus" (1958). By shifting the emphasis from penis to phallus, we may be able to see how Riviere has possibly misread her patient's imagined attacker as a father figure; it may be more pertinent to see him as occupying a position similar to that of the woman, insofar as he, too, might have reason to engage in masquerade to ward off retaliation by those who fear he has usurped their position of privilege. Before exploring the implications of such a rereading, however, I want to address the possibility that Riviere and her patient have subverted at least one aspect of hegemonic racism by imagining black men as equally capable as white men of serving as father figures. ${ }^{8}$ To perceive the black man as a father figure, in other words, might seem to lay the groundwork for restoring to black men the patriarchal power that had been historically denied them, even as it was deemed essential to masculine subjectivity. In this sense, it might be argued that according the black man the status of father figure is (in an antiracist project) a positively weighed fantasy. Such an imaginary "gift" to the black man is cruelly compromised, however, by the way in which the father figure is coded in Riviere's text: that which will punish women who dare to compete and that must therefore be seduced and diffused. If the black man was, indeed, perceived as a father figure by Riviere's patient, he was, at least in one version of the fantasy, soon divested of that status so that it could be restored to white male figures of authority.

It is then more in keeping with the real material conditions faced by black men in the 1920s to consider that, contrary to Riviere's interpretation, her patient may have perceived the "negro" of her fantasy as occupying a position much like her own, that is, that his claim to patriarchal power would, like hers, have been interpreted by white men as a transgression worthy of punishment. In Lacanian terms, both the woman and her "attacker" behave as though they possess the phallus, though only one of them has recourse to feminine masquerade as a defense against

8. My thanks to a reader at Critical Inquiry for prompting me to consider this interpretation of the passage. 
retaliation for such behavior. Riviere says of her patient that

the exhibition in public of her intellectual proficiency, which was in itself carried through successfully, signified an exhibition of herself in possession of the father's penis, having castrated him. The display once over, she was seized by horrible dread of the retribution the father would then exact. Obviously it was a step towards propitiating the avenger to endeavor to offer herself to him sexually. [“W," p. 37]

It is at this point that Riviere introduces the childhood fantasy of an attacking "negro," and she takes it for granted that since the black man has a penis that could be "stolen," he can therefore be interpreted as another version of the father figure whose anger must be assuaged. But, though the penis can be attributed to all men (as opposed to women), it must be pointed out that the phallus cannot. By fantasizing a black man, Riviere's patient is calling upon a figure whose relation to the phallus, as signifier of white male privilege in a racialized, patriarchal society, is as tenuous as her own.

Consider what takes place in the Riviere essay in terms of its implied elaboration of a phallic economy. According to Lacan, no one can really "have" the phallus, though men and women of all races may strive to appear to have it, with varying material repercussions. ${ }^{9}$ In the standard Freudian account of masculine subjectivity, what is perceived as a "lack" in women (that is, the absence of the penis) is not tolerable from the little boy's (nor apparently the man's) perspective. This "lack" in the woman is threatening because it means that the man may also lose his organ; hence, he feels the necessity on his part to disavow and cover over her "lack" via the fetish. ${ }^{10}$ In Lacan's work, the standard binary that forms itself around the phallus is not "having the phallus" on one side and "lacking the phallus" on the other. Rather, lack must, once more, be covered over; thus, in Lacan, the man must appear to "have the phallus" while the woman must appear to "be the phallus" (this way no one is "lacking" the phallus). Indeed, the woman must appear to "be the phallus" precisely so that the man may be assured that he "has" it. Judith Butler clarifies this in the following way: "For women to 'be' the Phallus means, then, to reflect the power of the Phallus, to signify that power, to 'embody' the Phallus, to supply the site to which it penetrates, and to signify the Phallus through 'being' its Other, its absence, its lack, the dialectical confirmation of its identity" (GT, p. 44). A masquerading woman in Lacan is one who mas-

9. The "relations between the sexes," Lacan says, "revolve around a being and a having" the phallus, which is in itself a matter of "appearing" to have the phallus, "so as to protect it on one side and to mask its lack on the other" (Lacan, "The Meaning of the Phallus," in Feminine Sexuality, pp. 83-84).

10. See Sigmund Freud, "Fetishism," The Standard Edition of the Complete Psychological Works of Sigmund Freud, trans. and ed. James Strachey, 24 vols. (London, 1953-74), 21:152-57. 
querades in order to be the phallus for the man, in order to be the phallus that he must be reassured he has.

Riviere's patient has placed herself in relation to her so-called lack in conflicting ways. At no point does her "lack" appear as such; when she speaks in a public forum, she appears as "having the phallus," and she rightly suspects that this will not be tolerated by her male audience. Thus, after the performance, through the masquerade, she reappears as "being the phallus," in order to reassure the listening men that they "have" it after all. But the introduction of the cross-racial fantasy signals that we are not dealing with a simple male/female binary at all; rather, a third term enters the picture. The fantasy of the attacking "negro" suggests that this woman's relation to the phallus, and thus to her "womanliness" as a masquerade, is inflected by her imagined relation to the black man's relation to the phallus. Riviere simplifies matters by seeing the black man as another representative of the "father" on the male side of a gender binary. But Riviere's patient is addressing her masquerade to two quite differently constructed male audiences. Consider the specific details of the fantasy again: "if a negro came to attack her, she planned to defend herself by making him kiss her and make love to her (ultimately so that she could then deliver him over to justice)." Since her "defense" is to seduce the attacker, it would appear that she does not regard his aggression to be sexually motivated at first. In other words, she understands him to be attacking her for other reasons. Given the historical realities of postslavery America, it is worth noting that she appears to "have" the phallus (that is, to be in a position of power and authority) both as a woman and as a white woman. As a white woman, her appearing to have the phallus is culturally sanctioned when it is a question of her relation to a black man. Historically, white men and women who had enjoyed the privileges of white supremacy in the South during slavery were, during and after Reconstruction, experiencing loss of power and perceiving it to be usurped by black men. To desire the phallus, then, as a white woman was to desire something both culturally proscribed (insofar as she was a woman) and culturally sanctioned (insofar as she was white) by a white hegemonic racist and patriarchal culture. The question is, How does the white woman negotiate this contradiction, particularly as it is played out in her fantasies about black masculinity?

By playing the masquerade to the black man as audience, she will appear to "be the phallus" in order that he will, in turn, want to have her as the phallus, to have her as the "site to which" he will penetrate. As soon as his imagined aggression has been thus defined as sexual in nature, she will then "deliver him over to justice." That "justice," of course, in the violently racialized context that is the American South, will likely consist in the literal castration and lynching of the offending black man at the hands of the white men whose legal and social prerogative it is to be the proper possessors of the phallus. In masquerading as the phallus for 
the black man, Riviere's patient will have succeeded in transforming him into the phallus, which she can then hand over to the true father figures in this scenario, the white men who are the administrators of the "justice" that is evoked. Indeed, according to Martha Hodes, though it might have been a black man's "political or economic authority and independence" that led to violent retaliation on the part of whites, that authority and independence were customarily linked to a supposed sexual threat he posed to white women, so that his lynching was understood to be a result of his sexual, as much as his political, aggression: "whether true or untrue, what comes through consistently in the testimony [of KKK witnesses] is the way in which extreme white anxiety over sexual liaisons between white women and black men was linked to fears of black men's political and economic independence." ${ }^{11}$ In Riviere's essay, then, we find evidence about the way in which this "extreme white [male] anxiety" inflects a white woman's attempt to negotiate her own "political and economic independence." Riviere notes that for this woman "womanliness ... could be assumed and worn as a mask, both to hide the possession of masculinity and to avert the reprisals expected if she was found to possess it-much as a thief will turn out his pockets and ask to be searched to prove that he has not the stolen goods" ("W," p. 38). While she can turn her pockets out and show that she has no penis after all, the black man she fantasizes about cannot do so, and his horrific punishment will be, after all, his literal castration and death.

There is a second part to the cross-racial fantasy, however, that complicates this picture somewhat. Again, Riviere sees the black man in the patient's dream as analogous to the father whose retribution the patient fears for having usurped his position. Her washing of the clothes is interpreted as her attempt to wash off the "dirt and sweat, guilt and blood, everything she had obtained by the deed" of killing her parents. However, it is just as plausible that this washing is evident of her desire, and her anxiety about this desire, to identify with blackness. As Sander Gilman has pointed out, it would have become a commonplace by the $1920 \mathrm{~s}$ to associate sexuality, and in particular a sexuality that exceeded or contradicted a clearly heterocentric model (as in the case of the prostitute, the lesbian, or the hysteric), with the image of the "hottentot," the stereotype of black female subjectivity. ${ }^{12}$ Interestingly, the patient's dream does not end with the turning over of the black man to "justice"; this time, she is content "'disguising herself' as merely a castrated woman," as Riviere

11. Martha Hodes, "The Sexualization of Reconstruction Politics: White Women and Black Men in the South after the Civil War," in American Sexual Politics: Sex, Gender, and Race Since the Civil War, ed. John C. Fout and Maura Shaw Tantillo (Chicago, 1993), pp. 65, 64.

12. See Sander L. Gilman, "Black Bodies, White Bodies: Toward an Iconography of Female Sexuality in Late Nineteenth-Century Art, Medicine, and Literature," in "Race," Writing, and Difference, ed. Henry Louis Gates, Jr. (Chicago, 1985), pp. 223-61; hereafter abbreviated "BB." 
puts it, so that he will caress her arms and breasts. Significantly, the only other erotic dreams she has are "frequent homosexual dreams with intense orgasm" (“W," p. 39). Up until this point, Riviere's patient has been presented as either superficially heterosexual (gaining satisfaction in sexual relations with her husband only because her anxiety is thus allayed) or as frigid. But, as Butler points out, Riviere's patient could be understood as a kind of "homosexual without homosexuality"; "the donning of femininity as mask may reveal a refusal of a female homosexuality and, at the same time, the hyperbolic incorporation of that female Other who is refused [the patient, through masquerade, becomes the object-that is, a woman-whom she forbids herself to love]" (GT, p. 53). Moreover, Butler explains, this predicament is "produced by a matrix that accounts for all desire for women by subjects of whatever sex or gender as originating in a masculine, heterosexual position. The libido-as-masculine is the source from which all possible sexuality is presumed to come" (GT, p. 53). If a person feels desire for a woman, in other words, this person must be understood to be desiring from a masculine, heterosexual position, since it is assumed that the libido is, by nature, masculine. But I would add that just as the cultural matrix is "[hetero]sexualized" in a certain way, it is also "racialized" in a certain way, and this must be taken into account in any consideration of how either "femininity" or sexuality is being constructed in psychoanalytic texts of the 1910s and 1920s. For if this matrix is marked by an assumption of the libido-as-masculine, it is also paradoxically marked by an equally coercive assumption of the libido-as-black, a trope that informed the fantasy life of more than one analysand in the early days of psychoanalysis and yet was not seriously interrogated until the work of Frantz Fanon.

\section{The Libido-as-Black and Phobogenic Objects}

In "Contributions to the Masculinity Complex in Women" (1917), Dutch analyst J. H. W. van Ophuijsen recounts his analysis of five women who suffer from a "masculinity complex." He notes with interest that three of the women "informed me of their own accord that they possessed 'Hottentot nymphae",; this fact, which they had already noticed very early in their lives, led them to the conviction that they were different from other women." ${ }^{13}$ By "Hottentot nymphae," van Ophuijsen means the supposedly enlarged female sexual organs that black women in Africa were reputed to possess. As Sander Gilman points out, ethnographic constructions of the "Hottentot" had become by the end of the nineteenth century (and, judging by van Ophuijsen's article, well into the twentieth)

13. J. H. W. van Ophuijsen, "Contributions to the Masculinity Complex in Women" (1917), in Psychoanalysis and Female Sexuality, p. 63. 
the paradigm of black female sexuality, notable less for her black skin than for the supposed abnormal development of her genitalia and buttocks. Anthropological and medical "research" in the nineteenth century served only to confirm the observations of eighteenth-century travelers who had "described the so-called Hottentot apron, a hypertrophy of the labia and nymphae caused by the manipulation of the genitalia" ("BB," p. 232). Throughout the century, African women were exhibited in Europe as examples of a "primitive" sexuality, dissected upon their death, and their genitalia put on display for scientific (and public) scrutiny. Thus, Gilman describes the fate of Sarah Bartmann, an African woman displayed throughout the early part of the century:

The audience which had paid to see her buttocks and had fantasized about the uniqueness of her genitalia when she was alive could, after her death and dissection, examine both, for Cuvier [a contemporary pathologist] presented to "the Academy the genital organs of this woman prepared in a way so as to allow one to see the nature of the labia." ["BB," pp. 232, 235]

The European fixation on the "Hottentot nymphae" endured for well over a hundred years according to Gilman: "Sarah Bartmann's genitalia and buttocks summarized her essence for the nineteenth-century observer, or, indeed, for the twentieth-century one, as they are still on display at the Musée de l'homme in Paris" ("BB," p. 235). Gilman also documents the continuing publication of books into the early twentieth century linking the "pathological" and "atavistic" sexuality of European prostitutes and lesbians to the "primitive" sexuality of the Hottentot. ${ }^{14}$

It is as though van Ophuijsen's patients sought to assert sexual and gender identities that would challenge and contradict the strictly (white) feminine one that had hitherto been culturally prescribed (and was about to become psychoanalytically codified) in terms of passivity, receptivity to the "active" male, and de-emphasis of the pleasures of the clitoris. Since it had become probable by the 1910s that defiance of the feminine role

14. For example, he notes a study of the "criminal woman," subtitled The Prostitute and the Normal Woman, by Cesare Lombroso and Guillaume Ferrero (1893) in which illustrations 'deal with the image of the Hottentot female and illustrate the 'Hottentot apron' and the steatopygia"; Lombroso "regards the anomalies of the prostitute's labia as atavistic throwbacks to the Hottentot" ("BB," p. 245). An 1870 text by Adrien Charpy "begins by commenting on the elongation of the labia majora in prostitutes, comparing this with the apron of the 'disgusting' Hottentots" ("BB," p. 248). In Theodor Billroth's 1877 handbook of gynecology, "a detailed presentation of the 'Hottentot apron' is part of the discussion of errors in development of the female genitalia" and "the Hottentot's anomalous sexual form" was linked to "the overdevelopment of the clitoris, which [Billroth] sees as leading to those 'excesses' which 'are called "lesbian love."' The concupiscence of the black is thus associated also with the sexuality of the lesbian" ("BB," p. 237). In 1905, Abele de Blasio "published a series of case studies on steatopygia in prostitutes in which he perceives the prostitute as being, quite literally, the Hottentot" (“BB," p. 248). 
would inevitably be "diagnosed" as a "masculinity complex" (that is, if you do not wish to be "feminine," you must wish to be "masculine"), these women would seem to have sought an alternative means of asserting a gendered identity that both was and was not officially "feminine." Drawing from the kinds of clinical or anthropological depictions of the genitals of African women that would doubtless have been circulating in the early twentieth century, they found images of themselves in a mirror that was striking for its racialized, not its masculine-gendered, depiction of sexual difference. If van Ophuijsen's patients are "claimers" (to use Freud's term, later promulgated by Marie Bonaparte, for women who refuse to renounce the sexual pleasure of the clitoris), it is an imagined black, but nevertheless female sexual identity they are claiming, not a male one. Yet, caught up in the rigid binary of masculine/feminine, in which blackas synonymous with genital and libidinal-is permanently subsumed under masculine, van Ophuijsen cannot acknowledge that these white women are enacting a specifically cross-racial, rather than crossgendered, identification. His ensuing observations reveal that, although he cannot find a "masculine disposition," "appearance," or "expression" in these women, he nevertheless takes their remarks as primarily indicative of their fantasies of possessing male genitalia:

I did not find to any great extent in any of these cases what is called a masculine disposition; nor indeed a masculine appearance and expression, a contempt for men, or a predilection for masculine activities. I would rather define the attitude present as one of rivalry with men in the intellectual and artistic spheres. ${ }^{15}$

Doubtless it is their "rivalry with men in the intellectual and artistic spheres" that has marked these white women as somehow deviant in terms of their sexuality or gender in the first place, and that might have prompted in them the same anxiety about white, male retribution felt by Joan Riviere's patient. Once again, a racialized Other is invoked by a woman as a means to distance herself from "femininity" while at the same time not seeming to encroach on "masculinity." But psychoanalysis as an institution was not able to theorize the importance of this, since it was not until Fanon's work that the category of the Other could be conceived of in racialized, as well as sexualized, terms.

In "The Negro and Psychopathology," Fanon reconsiders Lacan's theory of the mirror stage in an explicitly racialized context:

It would indeed be interesting, on the basis of Lacan's theory of the mirror period, to investigate the extent to which the imago of his fellow built up in the young white at the usual age would undergo an imaginary aggression with the appearance of the Negro. When one has grasped the mechanism described by Lacan, one can have no further

15. Van Ophuijsen, "Contributions to the Masculinity Complex in Women," p. 63. 
doubt that the real Other for the white man is and will continue to be the black man. ${ }^{16}$

This chapter of Black Skin, White Masks is an extended elaboration of the ramifications for psychosexual development in a culture that has fostered the production of the black body as "phobogenic" (that is, the cause of phobia in whites, and, more crucially, in blacks who have been brought up to believe they are white). To follow through on this analysis, Fanon draws upon, though does not explicitly acknowledge, the way in which the female body is also phobogenic (as that thing whose "lack" is so feared it cannot be perceived as such). Fanon's explanation of the white woman's fantasy "A Negro is raping me" supplies a striking counterpart to Joan Riviere's text. For in his text, too, the white woman who experiences such a fantasy is exemplary of "certain failures or certain fixations" in women who have not successfully acceded to their mature sexual roles as passive partners (BS, p. 178). Fanon relies without question on the work of Helene Deutsch and Marie Bonaparte, both of whom shared the general consensus in the debate of the 1920s that, as Fanon puts it,

alternatively clitoral and clitoral-vaginal and finally purely vaginal, a woman-having retained, more or less commingled, her libido in a passive conception and her aggression, having surmounted her double Oedipus complex-proceeds through her biological and psychological growth and arrives at the assumption of her role, which is achieved by neuropsychic integration. $[B S$, p. 178]

There remain vestiges in these women of an "active Oedipus complex," corresponding to "the clitoral stage," meaning that the clitoris is "perceived as a diminished penis," and that the girl, like the boy, has "impulses directed at the mother; she too would like to disembowel the mother" (BS, pp. 178-79).

This fantasy of disemboweling the mother is, by the time Fanon reiterates it, a commonplace in the psychoanalytic literature of male and female analysts alike. It makes up an obligatory component of Riviere's analysis:

In consequence of disappointment or frustration during sucking or weaning, coupled with experiences during the primal scene which is interpreted in oral terms, extremely intense sadism develops towards both parents. The desire to bite off the nipple shifts, and desires to destroy, penetrate and disembowel the mother and devour her and the contents of her body succeed it. These contents include the father's penis, her fæces and her children. ["W," pp. 40-41]

16. Frantz Fanon, Black Skin, White Masks, trans. Charles Lam Markmann (New York, 1967), p. 161 n. 25; hereafter abbreviated $B S$. 
Riviere is drawing directly from Melanie Klein, whose 1929 discussion of reparation I will consider at length in the next section of this article. Klein theorizes that

[the most profound anxiety experienced by girls] is the equivalent of castration-anxiety in boys. The little girl has a sadistic desire, originating in the early stages of the Oedipus conflict, to rob the mother's body of its contents, namely, the father's penis, faeces, children, and to destroy the mother herself. ${ }^{17}$

However, for each analyst (Klein, Riviere, Fanon) the way in which the woman will mitigate the anxiety produced by this fantasy is theorized differently; in all three cases, racial difference becomes an element in the analysis, but only in Fanon's text is it explicitly acknowledged. For Riviere, the daughter wards off anxiety by occupying her father's position, from which she can seem to put herself "at the service" of her mother:

In this appalling predicament the girl's only safety lies in placating the mother and atoning for her crime. She must retire from rivalry with the mother and, if she can, endeavour to restore to her what she has stolen. As we know, she identifies herself with the father; and then she uses the masculinity she thus obtains by putting it at the service of the mother. She becomes the father and takes his place; so she can 'restore' him to the mother. ["W," p. 41]

But, as we have seen, this strategy is inevitably inflected by fantasies of the attacking "negro" and of her own "blackness," which must be washed off. That it is possible to "steal" an imagined penis from the mother (that is, the father's penis in her) suggests again that the penis, or phallus, that is stolen from the attacking black man is imagined as originally belonging to the [white] father. Klein ignores the question of either penis or phallus, focussing on how a daughter effects "reparation" to her injured mother via artistic impulses, though, as we shall see, at least one of the paintings this daughter produces depicts a racialized figure that, once again, goes unremarked by the analyst. Fanon, however, brings racial fantasies to the forefront in his account of how a woman, still under the influence of an inadequately displaced clitoral sexuality, negotiates her anxiety about desiring to disembowel her mother.

As a young woman enters what Fanon calls "the folklore and the culture along roads that we know, the Negro becomes the predestined depositary" of her aggression towards the mother. Thus

when a woman lives the fantasy of rape by a Negro, it is in some way the fulfillment of a private dream, of an inner wish. Accomplishing

17. Melanie Klein, "Infantile Anxiety-Situations Reflected in a Work of Art and in the Creative Impulse” (1929), Love, Guilt, and Reparation and Other Works, 1921-1945 (London, 1975), p. 217; hereafter abbreviated "I." 
the phenomenon of turning against self, it is the woman who rapes herself. We can find clear proof of this in the fact that it is commonplace for women, during the sexual act, to cry to their partners: "Hurt me!" They are merely expressing this idea: Hurt me as I would hurt me if I were in your place. The fantasy of rape by a Negro is a variation of this emotion: "I wish the Negro would rip me open as I would have ripped a woman open." [BS, p. 179]

In Fanon, as in Riviere, there is a sense that a woman's racial fantasy occurs almost as a consequence of a "failure" to attain a fully mature femininity; or, rather, the fantasy becomes a means to negotiate her forbidden "masculine" tendencies. Here, the woman identifies with the black man who (via "folklore and the culture") is reputed to have the instrument she would need to disembowel her mother: a mythically larger-than-life penis. But as a woman she also occupies the position of the mother whom she wishes to disembowel, thus giving expression both to her "masculine" aggression and her guilt at this aggression. Though it is valuable for its critique of the libido-as-black, Fanon's analysis of the cross-racial rape fantasy nevertheless becomes a means to reify the myth of femininity as masochism; the fantasy can only be understood as a means for women to express their own self-destructive impulses, and no interrogation is made of the means by which the female (maternal) body must be constructed as a phobogenic object. In Riviere, on the other hand, the fantasy becomes a means to reify the myth of the black man as wielder of a threatening phallus; he can only be conceptualized as a father figure, so that both a significant aspect of his commonality with the white woman, as well as the specificity of his difference from her, are necessarily elided. Fanon is well aware of the specifically racialized matrix that informs the rape fantasy he considers; what he is not able to articulate is the heterocentric matrix that prompts him to posit this fantasy as symptomatic of a somehow failed white femininity, and to admit that he knows nothing about the woman of color (see BS, pp. 179-80). By the same token, the absence of an awareness of the racialized matrix subtending her patient's fantasy prevents Riviere, as well as most of the feminist critics who rely upon her, from seeing how womanliness as a masquerade is simultaneously a masquerade of whiteness.

\section{4. (White) Reparation with a Naked Negress in Melanie Klein}

In the same year that Riviere published her essay on female masquerade, friend and colleague Melanie Klein developed her theory of "reparation" in an essay that is, for our purposes, just as striking for its evocation and then dismissal of a racialized figuration in the fantasy life of a female subject. Though Klein was not primarily concerned with elaborating a theory of "femininity" or "female sexuality" at the time, she 
was careful to distinguish between the genesis of reparation in women as opposed to men; hence, her essay "Infantile Anxiety-Situations Reflected in a Work of Art and in the Creative Impulse" is divided in two parts, one focussing on a male, the other on a female subject. After discussing the male protagonist in the libretto of a Ravel opera (The Magic Word, written by Colette), Klein analyzes an essay entitled "The Empty Space" by Karin Michaelis, in which Michaelis gives a biographical sketch of her friend Ruth Kjär, a wealthy woman who becomes a painter and who is the "case study" upon which Klein bases her conclusions about the "earliest danger-situation in a girl's development" ("I," p. 215).

As we have already seen, Klein was instrumental in emphasizing early infantile aggression toward the mother and in theorizing its succession by a "reparation" phase, which becomes the source of creativity later in life. ${ }^{18}$ The story of Kjär, as Klein summarizes it from Michaelis's account, concerns a "beautiful, rich and independent" woman who, aside from a flair for interior decoration, has "no pronounced creative talent" ("I," p. 215). Although she seems to have a full life, is an active theater and concert goer, climbs mountains, and travels extensively, she experiences bouts of severe depression, which Michaelis describes in these terms:

"There was only one dark spot in her life. In the midst of the happiness which was natural to her, and seemed so untroubled, she would suddenly be plunged into the deepest melancholy. A melancholy that was suicidal. If she tried to account for this, she would say something to this effect: 'There is an empty space in me, which I can never fill!"” ["I," p. 215]

Kjär seems to experience some happiness after she is married, but the "empty space" returns and continues to haunt her. Klein quotes from Michaelis thus:

"Have I already told you that her home was a gallery of modern art? Her husband's brother was one of the greatest painters in the country, and his best pictures decorated the walls of the room. But before Christmas this brother-in-law took away one picture, which he had only lent to her. The picture was sold. This left an empty space on the wall, which in some inexplicable way seemed to coincide with the empty space within her." ["I," p. 215]

18. On the importance of Klein to more recent feminist theory, see Margaret Whitford's entry on Klein in Feminism and Psychoanalysis. Whitford suggests that Klein's influence on feminism has been only indirect (via object-relations theory, for instance), partly "because her work appears to locate FEMININITY and feminine heterosexual desire in innate drives" (p. 192). Recent publications, however, suggest a more direct "return" to Klein among feminists; see, for example, Rose, Why War? - Psychoanalysis, Politics, and the Return to Melanie Klein (Oxford, 1993), and Janice Doane and Devon Hodges, From Klein to Kristeva: Psychoanalytic Feminism and the Search for the "Good Enough" Mother (Ann Arbor, Mich., 1992). 
Unable to wait for a new painting from the brother-in-law, Kjär declares to her husband that she will "try to daub a little on the wall myself "” ("I," p. 215). This first effort launches a very successful painting career, which Klein briefly describes before explaining how this story illustrates her theory about infantile anxiety. "Now what is the meaning of this empty space within Ruth," Klein asks, "or rather, to put it more exactly, of the feeling that there was something lacking in her body?" (“I,” p. 216). We are already familiar with the answer:

The little girl has a sadistic desire, originating in the early stages of the Oedipus conflict, to rob the mother's body of its contents, namely, the father's penis, faeces, children, and to destroy the mother herself. This desire gives rise to anxiety lest the mother should in her turn rob the little girl herself of the contents of her body (especially of children) and lest her body should be destroyed or mutilated. [“I," p. 217]

The rest of the article is taken up with a description of the content of the paintings Kjär produced after her first attempt to fill the space; they are almost all portraits of female family members, the most significant ones (for Klein) depicting Kjär's mother first as an old, then as a young, woman. Klein remarks:

It is obvious that the desire to make reparation, to make good the injury psychologically done to the mother and also to restore herself was at the bottom of the compelling urge to paint these portraits of her relatives. That of the old woman, on the threshold of death, seems to be the expression of the primary, sadistic desire to destroy. The daughter's wish to destroy her mother, to see her old, worn out, marred, is the cause of the need to represent her in full possession of her strength and beauty. By so doing the daughter can allay her own anxiety and can endeavour to restore her mother and make her new through the portrait. In the analyses of children, when the representation of destructive wishes is succeeded by an expression of reactive tendencies, we constantly find that drawing and painting are used as means to restore people. ["I," p. 218]

As I have already mentioned, however, Klein's analysis is quite astonishing in its indifference to the content of the first painting Kjär produces to fill up the "empty space" on the wall and in herself. Kjär's husband is far from indifferent: "'She drew him with her, saying: "Come, you will see!" And he saw. He could not take his eyes from the sight; could not take it in, did not believe it, could not believe it"” ("I," p. 216). Her brother-inlaw is equally alarmed: "You don't imagine you can persuade me that you painted that! What a damned lie! This picture was painted by an old and experienced artist. Who the devil is he? I don't know him!'” (quoted in "I," p. 216). And yet, this same picture has no bearing on Klein's theory 
of reparation, since this is the only passing reference she makes to it: "In seeking the explanation of these ideas [of infantile anxiety and reparation], it is instructive to consider what sort of pictures Ruth Kjär has painted since her first attempt, when she filled the empty space on the wall with the life-sized figure of a naked negress" ("I," p. 217). The deemphasis of the racialized nature of this prelude to a series of portraits of the artist's mother and sister is all the more remarkable given that Michaelis, in the article from which Klein draws, gives special attention to the painting and even goes so far as to imply an identificatory relation between the artist and her subject matter.

In the opening of "The Empty Space," Michaelis notes that her friend is Danish and Irish Canadian, and then inexplicably she attributes to her "a couple dashes of black African blood" "ein paar schwarze Afrikablutspritzer"). ${ }^{19}$ Whether we can attribute this fantasy of mixed race to Michaelis or Kjär herself is uncertain, but Michaelis continues the suggestion in her second reference to Kjär's painting:

That night Ruth can not sleep much. The picture on the wall is painted, that is certain-it is not a dream. But how has it happened? And what next? Is painting like writing books? One says that every human being could write a book, the book about oneself. Should this picture-which by the way portrays a young negress-should this picture be the first and last at the same time? ["RK," pp. 204-5]

According to Michaelis, then, Ruth here considers the possibility that this first painting is, like one's first and only book, autobiographical. In her narration of the story, Michaelis has withheld the race of the woman in the painting until this moment, as though to strike the reader more emphatically with the notion that Kjär is giving outward expression to a felt identification with racial blackness. In the first reference to the painting, perhaps because she is eager to emphasize Kjär's unexpected artistic expertise, Michaelis leaves out indications of the woman's race, focussing primarily on her gender, on her posture, on composition and lighting: "The empty space is filled with a lifesized woman. She is half sitting, half lying, her skin is like gold, she lowers her face against one shoulder, the light falls through a small window. In front of this window an ebony table with a large stoneware pitcher" ("RK," p. 204). These are the details meant to convey to the reader what so astounds Kjär's artist brother-

19. Karin Michaelis, "Ruth Kjär," Flammende Tage: Gestalten und Fragen zur Gemeinschaft der Geschlechter (Dresden, 1929), p. 200; hereafter abbreviated "RK." This is a German translation of the same book written by Michaelis in Danish, published in the same year. It is possible that Klein read the article on Ruth Kjär in an English or German version published in a different forum with the title "The Empty Space." I am indebted to Beverley Driver Eddy, who is writing a biography on Michaelis, for having sent me a copy of the Kjär chapter in Flammende Tage. I would also like to thank my colleague Doris Kirschner for her English translation of this text. 
in-law; he cannot believe the painting has not been produced by an experienced, male artist (“Who the devil is he? I don't know him!"). In her narrow focus on the mother-daughter relation, Klein neglects to reflect on how this painting becomes Kjär's admission ticket to the male-defined and -dominated world of high artistic production. Her home, as we have been told, is a "gallery of modern art"; yet she cannot find herself, as artist, included among her brother-in-law's paintings. That she is yet another of van Ophuijsen's women who seek "rivalry with men in the intellectual and artistic spheres" seems suggested by the fact that she feels compelled to fill the empty space left by the male painter with an attempt of her own. Like Riviere's patient, by taking up the paintbrush and thereby endeavoring to usurp her brother-in-law's place as artistic producer, she risks being perceived as having "stolen" his token of masculinity. It is reasonable to suppose that she is as anxious about the father's as about the mother's retribution for her gender transgression.

The content of the first painting is crucial, then, to understand how it is designed to simultaneously effect Kjär's entry into a primarily male domain and placate potentially retaliatory father figures for having "stolen" the phallus. To paint a female nude is, perhaps, in and of itself to seek legitimacy as creator of high art. As Lynda Nead suggests: "More than any other subject, the female nude connotes 'Art'. The framed image of a female body, hung on the wall of an art gallery, is shorthand for art more generally; it is an icon of western culture, a symbol of civilization and accomplishment." ${ }^{20}$ To become an artist is to place oneself in a very specific position vis-à-vis the female body; it is to become the means by which that body is abstracted and contained:

The female nude can thus be understood as a means of containing femininity and female sexuality. If . . the female body has been regarded as unformed, undifferentiated matter, then the procedures and conventions of high art are one way of controlling this unruly body and placing it within the securing boundaries of aesthetic discourse. $[F N$, p. 2]

By attempting to maintain and police the "boundaries of aesthetic discourse," Kjär seeks to escape the body that stands for "unformed, undifferentiated matter," that same body which she has experienced as harboring an "empty space."

And yet Kjär paints, not simply a "female nude," but what Michaelis, at the end of her essay, refers to as a "lifesized figure of a naked negress." It is a representation of a woman's body that would seem to be racially differentiated from the artist's own, but she suspects it might be the

20. Lynda Nead, The Female Nude: Art, Obscenity, and Sexuality (London, 1992), p. 1; hereafter abbreviated $F N$. 
painted version of the "book about oneself." It is curious that, given her eagerness to assert Kjär's unexpected artistic talent, Michaelis uses the word naked at this point rather than the more high-toned nude. While much art-historical debate has attempted to establish and valorize a distinction between naked and nude, ${ }^{21}$ as Nead has pointed out, since "even at the most basic levels the body is always produced through representation. . . . There can be no naked 'other' to the nude" (FN, p. 16). Another way of putting this is to say that if there is a "naked 'other," it is not the body outside of representation but, rather, the body within a representation that is recognized, in some way, to be materially specific. Manet's Olympia bears what T. J. Clark sees as the "signs" of nakedness precisely because it indexes in some way its subject's social class. And, as Gilman points out in his 1985 reading of Olympia, the "signs" of nakedness include not only class but racial indicators. According to Gilman, Olympia is sexualized by the presence of her black servant, and, though she is a white prostitute, this whiteness is meant to be suspect. ${ }^{22}$ A nude, then, is a depiction of a (female) body whose whiteness is not in any way suspect, since it is assumed that to be white is not to be specifically "raced." To paint an unclothed black woman is, it would seem, by definition to paint a "naked," sexualized woman.

21. Nead clarifies the implications of this choice of terms in her genealogy of the nude/ naked debate in art-historical discourse. Drawing from the work of Kenneth Clark, John Berger, and T. J. Clark, Nead documents a persistent binary that characterizes these writers' positions, concluding with Clark's praise for the "nakedness" of Manet's Olympia because it is a "sign of class (or, more precisely, working-class) identity," thus refusing to function as a classical nude, which would be "'a picture for men to look at, in which Woman is constructed as an object of somebody else's desire" $(F N$, p. 16). As Nead points out, however, in the work of all three art historians "the discourse on the naked and the nude ... depends upon the theoretical possibility, if not the actuality, of a physical body that is outside of representation and is then given representation, for better or for worse, through art" ( $F N$, p. 16).

22. Indeed, that part of Olympia's specificity is her "blackness" is attested to by Picasso's satiric rendition of the painting in 1901, which Gilman describes thus:

Olympia is presented as a sexualized black, with broad hips, revealed genitalia, gazing at the nude flâneur bearing her a gift of fruit, much as Laura bears a gift of flowers in Manet's original.... Picasso owes part of his reading of the Olympia to the polar image of the primitive female as sexual object, as found in the lower-class prostitutes painted by Vincent van Gogh or the Tahitian maidens à la Diderot painted by Paul Gauguin. Picasso saw the sexualized female as the visual analogue of the black. ["BB," p. 251]

Gilman points out that, in a later painting depicting Zola's Nana, the white prostitute has taken on the characteristics that had been established by medical discourse as typical of the "Hottentot": plumpness, pronounced buttocks, and the atavistic "Darwin's ear." "Thus," writes Gilman, "we know where the black servant is hidden in Nana-within Nana. Even Nana's seeming beauty is but a sign of the black hidden within" ("BB," p. 251). For Gilman, "Manet's Nana thus provides a further reading of his Olympia, a reading which stresses Manet's debt to the pathological model of sexuality present during the late nineteenth century" (“BB," p. 251). 
Why, then, might Ruth Kjär expect her first painting to accomplish the double task of effecting her entry into the male domain of high art while simultaneously deflecting retaliation from angry father figures whose phallus she has "stolen"? As a wealthy woman who travelled extensively and whose house was a "gallery of modern art," Kjär was no doubt familiar with the tradition of the (white) female nude and its naked black counterparts in Manet, van Gogh, Gauguin, and Picasso. Michaelis's varying descriptions of Kjär's "naked negress" suggest that its status within the tradition of this naked/nude dichotomy is ambiguous. The painting is described, at first, as a semi-reclining woman with "skin like gold," lit by the light falling through a window, her racial identity displaced perhaps onto the "ebony table" nearby; then later she is described as "a young negress"; it is not until the end of the sketch that Michaelis reveals that she is unclothed, referring to her as "the lifesized composition of the naked negress" (the term Klein adopts). Thus we are, by turns, invited to consider her status first as a classically arranged figure belonging to the abstract, universal domain of the aestheticized female body, then as a particularized female figure insofar as she is designated by a racial term, then finally as both racialized and "naked" (rather than "nude"), which would seem to contradict the implied classicism of the first description. If Kjär has presumed to fill an "empty space" hitherto reserved for the male paintbrush, it is possible that, by this ambiguous depiction of an unclothed female body that is at once both black and classical, she hopes, like Riviere's patient, to appear to restore the phallus to its "rightful" wielders. The "naked negress," like the "attacking negro," could be interpreted as a kind of sacrifice within the gendered scene of power negotiations between a white woman and the white men whose retaliation she fears. Indeed, just as Riviere's patient imagines she will "deliver to justice" her attacking "negro," so too Michaelis invokes the authority figures by whom Kjär's paintings will be judged: "Now that the first pictures are being brought before the right art criticism, whose duty it is to show mistakes, one will say that Ruth Kjär is supposed to 'learn"” ("RK," p. 206).

But Michaelis follows this line of thought by proposing that Kjär be exempt from such judgment and therefore exempt from the necessity of "learning" or being officially trained as an artist. "But it is smarter if she didn't ['learn']. Because what she has now she has because of God's grace" ("RK," p. 206). It is as though an implied double primitivism is finally being admitted here: Kjär paints "primitively" because she has no prior training, and the first thing she paints is a "primitive" "naked negress." It might be suggested that her masquerade is a masquerade of "primitiveness"; the potentially retaliatory brother-in-law need not punish Kjär for having stolen the paintbrush since she is not an artist in the sense that he is an artist; rather, as her "self-portrait" as "naked ne- 
gress" will attest, she is an untutored primitive whose nakedness reveals no stolen instrument.

Even within the terms of a theory of reparation, where both Kjär's "empty space" and her reparative painting are understood to have resulted from anxiety about an infantile desire to disembowel her mother, Klein's admission of, then subsequent silence about, the racialized content of that first painting is suspect. That Klein's theory is predicated upon an example containing this unexamined representation suggests that it is, in itself, a theory of a specifically white female subjectivity. Klein closes the essay by noting that, although the "earliest anxiety-situation" for girls arising from fantasies of aggression towards the mother may "be the cause of serious illness and many inhibitions," "the case of Ruth Kjär shows plainly that this anxiety of the little girl is of greatest importance in the ego-development of women, and is one of the incentives to achievement" ("I," p. 218). Klein's theory has been valorized for its contradiction of Freud's schema, in which the woman's "super-ego is never so inexorable, so impersonal, so independent of its emotional origins as we require it to be in men" because it is only those who can be threatened by castration-that is, those who have penises-who will experience an "incentive" to cultural achievement. ${ }^{23}$ Klein, on the other hand, insists that both ego and superego are possible in women; moreover, they do have "incentives to achievement" by virtue of their fear, if not of castration, then of being disemboweled by a retaliating mother. Yet it turns out that, at least in one representative case, such incentive is announced by a reparative image that tells us the white female imaginary is occupied not only by a fantasized retaliatory white mother but also by a racially differentiated Other. This Other is not male, not white, and apparently crucial in negotiating how attempts at achievement will be received in a world where achievement is traditionally a white man's prerogative. The filling of a psychological empty space with a naked negress was clearly a significant trope for both Kjär and her enthusiastic biographer. But something about the specific obsessions of psychoanalysis prevented Klein, the third white woman in this mise-en-abime of female representations, from exploring that significance in such a way that it might seriously transform the institution she was both entering and creating.

\section{Conclusion}

Psychoanalytic feminist theory participates in what can only be a selfdefeating process of disavowal insofar as it deploys psychoanalysis as a

23. See Freud, "Some Psychical Consequences of the Anatomical Distinction between the Sexes," Standard Edition, 19:248-58. 
means of rewriting female subjectivity yet remains silent about race. ${ }^{24}$ Given the urgency that still informs (since the 1910s and 1920s) the projects of feminist and lesbian interventions in psychoanalysis, and in psychoanalytically informed feminist critique, it has seemed strategically crucial to bracket off, elide, ignore, or trivialize the ways in which race (however that may be constructed in a specific context) might manifest itself in the process of theoretical, social scientific, and identity-driven investigations. While it is not always made explicit, the assumption seems to be that instances of racialized identifications and desires must be separated or siphoned off from case material (such as Riviere and Klein's) that seems particularly promising as a matrix for interrogating how gender and sexuality have been constructed, performed, and policed. By removing or ignoring race, the case material can thus be restored to a more "pure" state in which an exploration of gender can proceed unhindered by "extraneous" considerations.

The Riviere essay is perhaps the most striking case in point. It may be that its enduring fascination for feminist scholars of both gendered and sexual subjectivity inheres only partly in its elaboration of femininity as a masquerade. While masquerade has undergone a richly diverse array of theoretical reinscriptions, revisions, and transformations, Riviere's indifference to the racialized components of her patient's fantasies is reproduced with a striking monotony by her feminist successors. It would seem, thus, that the peculiar readiness of Riviere's essay as a "usable" text lies to a great extent in the permission it gives to invoke, only to ignore, the cultural constructions of race that inform it, the better to focus on the more seemingly universal issues of gender and sexuality. With the exception of Emily Apter's discussion of masquerade in her book Feminizing the Fetish, Mary Ann Doane's appropriation of Riviere's work is the only one I know of to have at least mentioned in passing that

Riviere's patient has a number of sexual fantasies linking blacks, sexuality, power, and degradation-fantasies which are rarely, if ever,

24. Toni Morrison's book Playing in the Dark: Whiteness and the Literary Imagination (Cambridge, Mass., 1992) offers a literary analogue to this disavowal. In the long essay "Black Matters," Morrison notes with fascination the way in which some of the most powerful literary critics, in their "lavish exploration of literature" manage "not to see meaning in the thunderous, theatrical presence of black surrogacy-an informing, stabilizing, and disturbing element-in the literature they . . . study" (p. 13). As a critic who is herself a writer, Morrison came to realize that in literature written by whites, "the fabrication of an Africanist persona is reflexive; an extraordinary meditation on the self; a powerful exploration of the fears and desires that reside in the writerly conscious. It is an astonishing revelation of longing, of terror, of perplexity, of shame, of magnanimity" (p. 17). Instead of turning politely away from the racial constructions in the "great" white texts of Western literature, Morrison urges that we interrogate the precise ways in which the compelling richness and complexity of these texts depend upon and are buttressed by those racial constructions. 
discussed in the critical accounts of Riviere's concept of masquerade. [FF, p. 38]

And yet, in her 1991 book Femmes Fatales, even Doane restricts her analysis of psychoanalytic constructions of race to a separate chapter on Freud's "dark continent" trope ${ }^{25}$ though she makes mention of the racial material in Riviere, her two chapters on feminine masquerade proceed as if a discussion of female subjectivity could somehow transcend, or forget, its racialized contexts.

Emily Apter's reference to the racial fantasy of Riviere's patient is, like Doane's, also somewhat cursory and functions merely as a supplement to her analysis of why the concept of masquerade is inferior to the concept of the fetish as the grounding for a feminist elaboration of femininity. She points out that "with its language of veils, masks, and sexual travesty, the discourse of the masquerade seems always to participate in the very obfuscation of femininity that it seeks to dispel." ${ }^{26}$ But if feminists are not convinced by this argument (Apter seems to imply), then they might want to dissociate themselves from Riviere on the basis that to rely upon her case study would be to participate in racist assumptions. Apter concludes her brief discussion of the racial fantasy in Riviere by suggesting that the "lesson we might draw" from it is that "the chosen prototype of the masquerading woman is a problematic figure-abstracted from history and culture and blind to the psychosexual politics of racism." ${ }^{27}$ As I have suggested, however, it is precisely the way in which Riviere, and her masquerading woman, are problematic that makes them especially promising as prototypes for understanding how femininity has been constructed and played out within its particularly racialized contexts.

Teresa de Lauretis provides a striking example of how foregrounding the (racially) problematic prototype is equally important in

25. In "Dark Continents" in $F F$, Doane offers a rich exploration of the implications of Freud's trope of the "dark continent" as a metaphor for female sexuality, as well as a critique of the sexual politics in Fanon's texts, and suggestive readings of The Birth of a Nation and Sirk's Imitation of Life. And yet, even though the term masquerade reappears in this chapter, it has by this time been evacuated of its valence as a concept for (white) female subjectivity, and functions rather as a generalized indicator for how "Blackness is a costume which is worn or removed at will by whites [as in blackface], while whiteness in its symbolic dimension (the white robes of the Ku Klux Klan) is also a form of masquerade which conceals an identity" ( $F F$, p. 229). What would happen in Doane's reading of The Birth of a Nation, for example, if the link were made explicit between the woman in Riviere's case study and the Lillian Gish character, Elsie, who must be saved from the lustful desire of Silas Lynch? Or, more to the point, how might our understanding of Riviere be altered if we were to see her as sharing in the same white fantasy of racialized sexuality that informs the Griffith film?

26. Apter, Feminizing the Fetish, p. 90.

27. Ibid., pp. 91-92. 
the project of elaborating specifically lesbian subjectivities. In discussing van Ophuijsen's article on the "masculinity complex" in her book The Practice of Love: Lesbian Sexuality and Perverse Desire, de Lauretis restricts her consideration of the racialized trope of the "Hottentot nymphae" to a "brief digression" (that is, presumably not central to her critical exploration of the construction of female homosexuality in psychoanalytic literature) (PL, p. 35). After summarizing Gilman's work on the Hottentot Venus, de Lauretis directs our attention to the work of Carla Scott, whose Ph.D. qualifying essay, “The Hottentot Effect: The Crisis of Black Lesbian Representation" sketches out how black lesbian narratives such as Audre Lorde's Zami can function as "sites of resistance to 'the legacy of the Hottentot Venus' and as the creation of a new discursive space for theorizing black lesbian subjectivity" ( $P L$, pp. 36-37). The project of specifying and reclaiming black lesbian subjectivity is, indeed, a crucial one. Yet, this section of de Lauretis's text tends to give the impression that white women's fantasies of having "Hottentot nymphae" are more pertinent to an investigation of black than of white female subjectivity. The "sexuality" in de Lauretis's book title is marked only as "lesbian," not as "white," unwittingly, perhaps, making the book seem to pose as establishing a racially unmarked theory of lesbian subjectivity (its whiteness barely acknowledged) to be supplemented by other racially marked "versions" in texts such as Scott's.

This problem is reproduced in "Recasting the Primal Scene," de Lauretis's otherwise brilliant reading of Sheila McLaughlin's film She Must Be Seeing Things, which first appeared as "Film and the Visible" in How Do I Look? Queer Film and Video (the published version of papers given at a conference by the same name in New York in 1989) and then revised and incorporated into The Practice of Love. In the transcription of the discussion that followed de Lauretis's paper at the New York conference, de Lauretis is asked if she can "say something about the critique of She Must Be Seeing Things [which depicts a white woman and a black Latina in a lesbian couple] in regard to its treatment of racial difference." In response, de Lauretis notes that a common objection to the film "seems to be that [it] poses the question of racial difference, but then avoids it by collapsing it into questions of cultural or ethnic difference. This observation strikes me as correct, but I don't think the film allows one to deal with it beyond locating it as a problem." Because, as she explains, the film does not explicitly address its own construction of racial difference in a way that would allow her to "rethink and say something interesting about the relations of race, sexuality, and desire," she remains adamant throughout the discussion period (during which she is challenged repeatedly on the issue) that there is little more to be said, in the context of her project, about the film's depiction of race. She contrasts the film to "other lesbian texts that do not elide race, like Audre Lorde's Zami" and Cherríe Moraga's play Giving up the Ghost, which have allowed her to write about 
"the issue of race in feminist theory and in lesbian representation." ${ }^{28}$ Though she makes reference to them in a brief footnote, the conference participants' questions about the racial trope in She Must Be Seeing Things, as well as de Lauretis's consideration of them, are dropped from the version of her reading of the film that appears in The Practice of Love, the better to foreground the film's primary concern with "sexuality and fantasy" as well as how it is "informed by the critique of representation produced by the work of avant-garde filmmakers as well as feminist film critics and theorists" ( $P L$, p. 86). Not surprisingly, given her interest in the work of (white) "feminist film critics and theorists," de Lauretis's reading of McLaughlin evokes once more Riviere's masquerade essay and the feminist uses to which it has been put, without remarking on the racial trope at the center of the essay or elaborating on how it might inform subsequent white women's (indeed, white lesbians') fantasies of racial difference. Having asked how Riviere's white patient engages in culturally produced and reinforced fantasies of racial difference in order to negotiate proscribed intellectual pursuits as well as prohibited sexual desires, we might then ask how a white lesbian filmmaker like McLaughlin either reproduces or departs from Riviere as she mobilizes locally constructed assumptions about racial difference in the 1980s and 1990 s, even though, like Riviere, she is not explicitly foregrounding those assumptions in her project. As I hope I have been suggesting, analysis of white-authored works that evoke, even as they elide, race can tell us much about the "issue of race in feminist theory and lesbian representation," in particular, about how to make visible the otherwise unmarked whiteness of such texts and of how they subtend the whiteness of "lesbian sexuality" as it has been constructed thus far. The rich and subtle work of white lesbian/feminist theorists such as de Lauretis can no longer afford to bracket off the question of how white fantasies of racial difference, whether or not they seem to be about race, inflect the work they do.

I have brought into view the racialized components in the case studies by Riviere, van Ophuijsen, and Klein not in order to displace the theorizations of gender and sexuality enabled by those texts but to foreground how those theorizations depend upon an $u n$ theorized racial domain. So far, white-authored psychoanalytic attempts to make an argument for a specifically "feminine" or "female" subject-position have only succeeded by their persistent refusal to ask questions about the historically determined whiteness of the models they employ. Feminism as an institution has thus reenacted, perhaps, the way in which psychoanalysis as an institution (as illustrated by the Jones/Malinowski debate) defensively armored itself against charges of ethnocentrism. Having acknowledged this, I would suggest that the project now seems to be to

28. Nancy Graham et al., "Discussion," in How Do I Look? Queer Film and Video, ed. Bad Object-Choices (Seattle, 1991), pp. 264, 273, 268-69. 
investigate, in very specific and detailed ways, local constructions of racialized identification and desire, especially in those areas where the discourses of psychoanalysis and feminism intersect and enrich each other ${ }^{29}$ The objective of such a project would not be to establish a more comprehensive ontology of femininity, or of female or lesbian sexuality but, rather, to interrogate the ways in which the feminist ontologies hitherto constructed are implicated in a vexed genealogy of racialized discourse. We need to expose and address the way in which whiteness has come to pose as deeply constitutive of female subjectivity, even in the most groundbreaking work of feminists to date.

29. Elizabeth Abel has undertaken a project analogous to this one in her comprehensive and provocative essay "Black Writing, White Reading: Race and the Politics of Feminist Interpretation," Critical Inquiry 19 (Spring 1993): 470-98. See also Racializing Female Subjectivities: Feminism, Psychoanalysis, Cultural Production, ed. Abel, Barbara Christian, Helene Moglen (forthcoming). 